\title{
Assessment of Cognitive Phenotyping in Inbred, Genetically Modified Mice, and Transgenic Mouse Models of Alzheimer's Disease
}

\author{
Dong-Hee Kim ${ }^{1}$, Yoon-Sun Jang ${ }^{1}$, Won Kyung Jeon ${ }^{2,3}$ and Jung-Soo Han ${ }^{1 *}$ \\ ${ }^{1}$ Department of Biological Sciences, Konkuk University, Seoul 05029, ${ }^{2}$ Herbal Medicine Research Division, Korea Institute of \\ Oriental Medicine, Daejeon 34054, ${ }^{3}$ Convergence Research Center for Diagnosis, Treatment and Care System of Dementia, \\ Korea Institute of Science and Technology, Seoul 02792, Korea
}

Genetically modified mouse models are being used predominantly to understand brain functions and diseases. Well-designed and controlled behavioral analyses of genetically modified mice have successfully led to the identification of gene functions, understanding of brain diseases, and development of treatments. Recently, complex and higher cognitive functions have been examined in mice with genetic mutations. Therefore, research strategies for cognitive phenotyping should be sophisticated and evolve to convey the exact meaning of the findings and provide robust translational tools for testing hypotheses and developing treatments. This review addresses issues of experimental design and discusses studies that have examined cognitive function using mouse strain differences, genetically modified mice, and transgenic mice for Alzheimer's disease.

Key words: Hippocampus, Mice, Water maze, Fear conditioning, Object recognition, Prefrontal cortex

\section{INTRODUCTION}

Genetically modified mouse models allow us to better understand brain functions, causes of brain diseases, and develop therapeutic treatments. Anatomical, biochemical, physiological, and behavioral analyses of genetically modified mice provide insights into the influences of a target gene on brain function and behavior. Because the final output of the nervous system is behavior, behavioral measures are essential for analyzing these mice. Therefore, the success of genetically modified mouse models depends on a

Received February 2, 2019, Revised March 18, 2019,

Accepted March 25, 2019

* To whom correspondence should be addressed.

TEL: 82-2-450-3293, FAX: 82-2-3436-5432

e-mail: jshan06@konkuk.ac.kr robust, well-replicated phenotype [1-3]

The behavior of rats is well characterized and there is a long and illustrious literature regarding the measuring of cognitive functions, including learning and memory, with well-validated and controlled experimental design and methods [1]. However, environmental factors and the animal handling of the experimenter may confound behavioral data $[4,5]$. Therefore, to ensure accurate interpretation of cognitive phenotypes, experimental designs, including appropriate control groups and experimental procedures, have been elaborated $[3,6-8]$ and should be implemented in future studies. In addition, control measures of general health, sensory abilities, and motor function are examined to avoid over-interpretation and misinterpretation of experimental results $[1,2]$.

What is more important than these points mentioned above is that a researcher understands mouse behavior, along with a deep understanding of the research field. In particular, these comments
Copyright $\odot$ Experimental Neurobiology 2019. www.enjournal.org
This is an Open Access article distributed under the terms of the Creative Commons Attribution Non-Commercial License (http://creativecommons.org/licenses/by-nc/4.0) which permits unrestricted non-commercial use, distribution, and reproduction in any medium, provided the original work is properly cited. 
are further emphasized when studying cognitive function and diseases with cognitive impairments such as Alzheimer's disease (AD). Therefore, we first describe differences between mouse strains with respect to cognitive function and then introduce a number of studies that have revealed the neurobiological basis of cognitive functions using genetically modified mice. Finally, cognitive behavioral assays for AD transgenic mice are reviewed and comments regarding future directions are presented.

\section{COGNITIVE DIFFERENCES IN INBRED STRAINS OF MICE}

Inbred strains of mice are useful in the study of the association between cognitive traits and neurobiological functions [9-13]. Because each mouse in an inbred strain can be virtually identical in genotype, the cognitive characteristics of inbred mice can be related to neurobiological characteristics of the same strain of mice. Hence, numerous studies that show behavioral differences in inbred strains of mice can provide criteria in selecting a background strain for constructing genetically modified mice and in evaluating these behavioral results. For example, these studies can be informative in analyses of a hippocampal phenotype that differs between the comparison strains. Specifically, because DBA/2 mice show a specific behavioral profile, together with a deficiency in synaptic plasticity and a signaling pathway in the hippocampus [14-21], this strain may be a suitable model for the study of mutant mice with the goal of enhancing hippocampal-dependent learning and memory $[22,23]$. On the other hand, these studies indicate that, compared with other inbred strains including DBA/2 mice, C57BL/6 mice may be the strain with a superior background for the genetic analysis of the molecular/cellular mechanisms underlying hippocampus-dependent learning and memory $[8,11$, $12,19,20,24,25]$. Therefore, in this section of the present review, behavioral differences between C57BL/6 and DBA/2 mice, which have been used for developing transgenic or knock-out mouse models, are presented focusing on behavioral tasks that measure hippocampus-dependent learning and memory.

\section{Spatial version of the morris water maze}

The C57BL/6 and DBA/2 strains have been shown to have relatively similar performances in some behavioral assessments using the water maze [26-29]. However, other studies have reported that C57BL/6 and DBA/2 mice differed in their performance on tasks that required hippocampal integrity. C57BL/6 mice performed significantly better than DBA/2 mice on a stationary hidden platform version of the water maze task (place training) [25] and context fear conditioning [19].

Despite these discrepancies in behavioral reports, two strain differences in the neurobiological mechanisms support the behavioral superiority of $\mathrm{C} 57 \mathrm{BL} / 6$ mice in hippocampus-dependent tasks over DBA/2 mice. For example, C57BL/6 mice show greater long-term potentiation and higher expression levels of protein kinase $\mathrm{C}$ in the hippocampus than DBA/2 mice $[16,18,30]$. Interestingly, even though both C57BL/6 and DBA/2 mice performed with similar accuracy in either the place or visible platform training (cued training), hippocampal phosphorylated cAMP response element-binding protein (pCREB) levels were higher in C57BL/6 than in DBA/2 mice after place training, while no differences in hippocampal pCREB levels were reported between the two inbred mice strains after cued training $[8,31]$. These findings indicate that the hippocampus is better engaged in place training in $\mathrm{C} 57 \mathrm{BL} / 6$ mice than in DBA/2 mice.

Additional evidence that $\mathrm{C} 57 \mathrm{BL} / 6$ mice are better place learners or use better place strategy compared to DBA/2 mice comes from studies using a different maze task or a modified water maze task. First, C57BL/6 mice have been shown to choose a better place strategy in a plus maze task compared to DBA/2 mice [24]. Furthermore, strategy preferences of $\mathrm{C} 57 \mathrm{BL} / 6$ and $\mathrm{DBA} / 2$ mice were assessed in a redundant place/cued version of the water maze task, which was developed in a study by McDonald and White [32]. In the modified task, mice received training using a stationary visible platform for 2 days and then using a stationary submerged platform for 2 days. The 4-day sequence was repeated twice. On the final (competition) day, a visible platform was positioned in the quadrant opposite to where it had been located throughout training (see Fig. 1A). Mice were released at starting points equidistant from the training platform and the newly located, visible platform to assess place/cued strategies. As shown in Fig. 1B, mice that visited the training platform location prior to escaping to the visible platform were classified as "place responders," whereas those swimming directly to the visible (cued) platform were classified as "cued responders." The number of place responders was higher in C57BL/6 than in DBA/2 mice [8].

It is notable that in the strategy preference task, as the cued and subsequent place training progressed, $\mathrm{C} 57 \mathrm{BL} / 6$ mice performed better than DBA/2 mice on the third place learning task [8]. Therefore, a subsequent experiment was conducted to examine how prior learning affected subsequent learning. Training in the water maze consisted either of cued training followed by place training or the reverse order (i.e., place training followed by cued training) (Fig. 2). Both strains of mice showed equivalent performance in the initial cued or place training (Fig. $2 \mathrm{~B}$ and $2 \mathrm{C}$ ). However, C57BL/6 mice performed significantly better than DBA/2 mice, both in place training followed by cued training and in cued training followed by place training (Fig. 2B) $[6,33]$. These findings 
A

\begin{tabular}{|c|c|c|c|}
\hline Cued Training & Place Training & Cued Training & Place Training \\
\hline Day 1-2 & Day 3-4 & Day 5-6 & Day 7-8 \\
\hline Cued Training & Place Training & Competitio & \\
\hline Day 9-10 & Day $11-12$ & Day 13 & \\
\hline
\end{tabular}

B

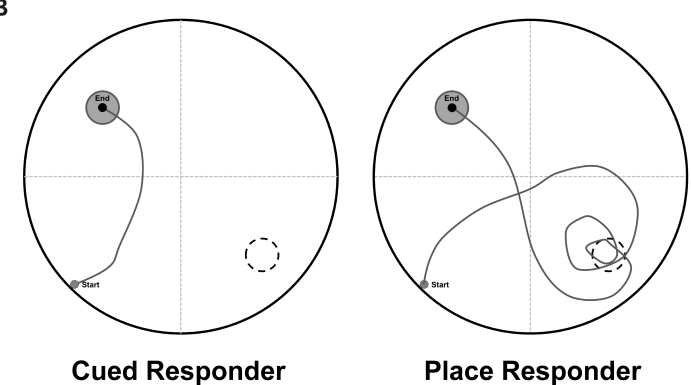

Fig. 1. Procedure for a redundant place/cued version of the water maze task. The platform is visible on days 1,2, 5, 6, 9, and 10 and hidden on days $3,4,7,8,11$, and 12 (A). On the competition test (day 13), swim paths from a representative mouse that swam directly to the visible platform in its new location (left, i.e., cued responder) and a representative mouse that crossed the annulus where the escape platform had been during the previous $12 \mathrm{~d}$ of training (right, i.e., place responder) (B).

indicate not only differences between the two inbred strains in the flexibility of C57BL/6 and DBA/2 mice to switch their learning strategies, but also suggest the importance of designs and training procedures to demonstrate experimental hypotheses.

\section{Fear conditioning}

Pavlovian fear conditioning is a form of associative learning in which an initially neutral stimulus, such as a tone (conditioned stimulus; CS), is paired with the presentation of a stimulus with aversive properties, such as a foot-shock (unconditioned stimulus; US). Freezing responses, an expression of associative fear learning, are elicited by CS presentation or by environment/context cues where the pairing occurred. Several types of fear conditioning have been used in animal studies (Fig. 3). Delay conditioning, in which discrete CS and US co-terminate, is dependent upon the amygdala $[34,35]$, while contextual conditioning, in which the environment serves as the CS, is dependent upon the hippocampus [36,37]. Another hippocampus-dependent type of fear conditioning is trace conditioning, in which the CS and US are separated by a stimulusfree trace interval [38], and which has been used in numerous studies with genetically modified and inbred mice, along with context conditioning [14, 15, 19, 29, 30, 39-45].

While there are many training procedures in the literature that have examined trace fear, a training procedure to minimize nonassociative effects was developed and performed by Smith et al. (2007) to demonstrate strain differences in performance in trace
A
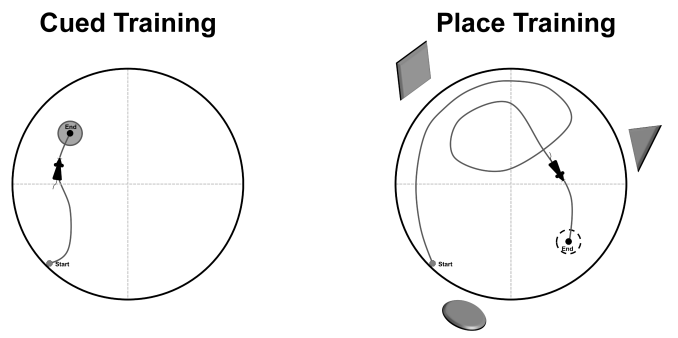

B
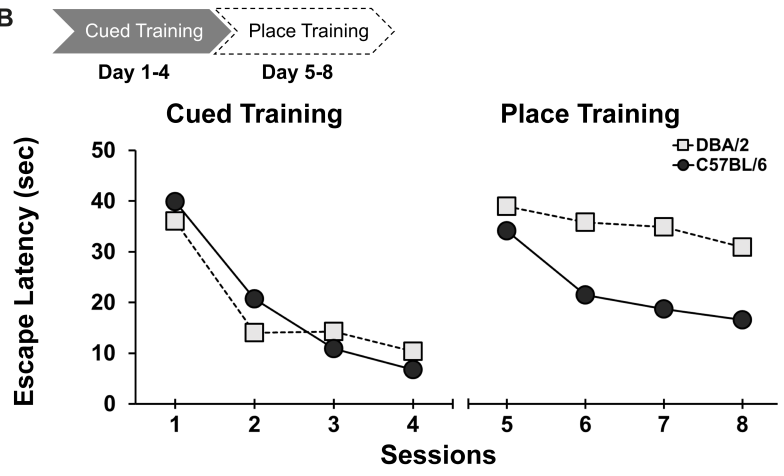

C

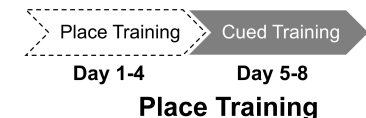

Place Training

Cued Training

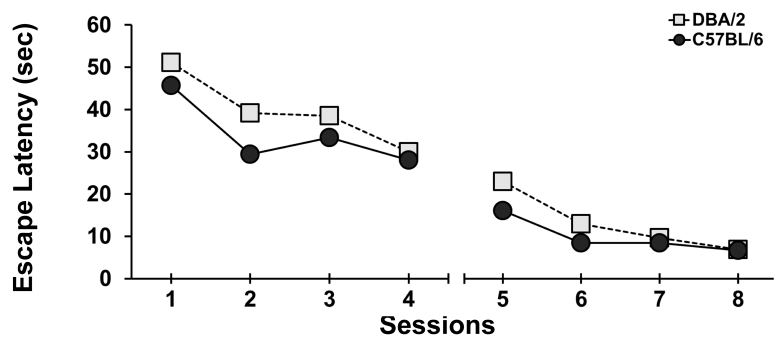

Fig. 2. Cued training (left) and place training (right) in the learning strategy-switching task (A). In a recent experiment [6], both C57BL/6 and $\mathrm{DBA} / 2$ mice received cued training for 4 days and then place training for 4 days. In the switched place training, C57BL/6 mice performed better than DBA/2 mice (B). A different cohort of C57BL/6 and DBA/2 mice received place training first, followed by cued training. In the switched cued training from place training, $\mathrm{C} 57 \mathrm{BL} / 6$ mice also performed better than $\mathrm{DBA} / 2$ mice (C).

fear conditioning in mice. Subsequent studies using the same training procedure of trace fear conditioning compared differences in freezing responses between $\mathrm{C} 57 \mathrm{BL} / 6$ and $\mathrm{DBA} / 2$ mice. The C57BL/6 mice displayed higher freezing responses to the tone-CS during testing than DBA/2 mice. Hippocampal levels of pCREB measured after conditioning were higher in C57BL/6 than in DBA/2 mice [17]. These findings provide additional evidence for the superiority of C57BL/6 mice over DBA/2 mice in hippocampus-dependent tasks.

\section{Novel object recognition task}

The novel object recognition task has emerged as one of most 


\section{A Delay Fear Conditioning}

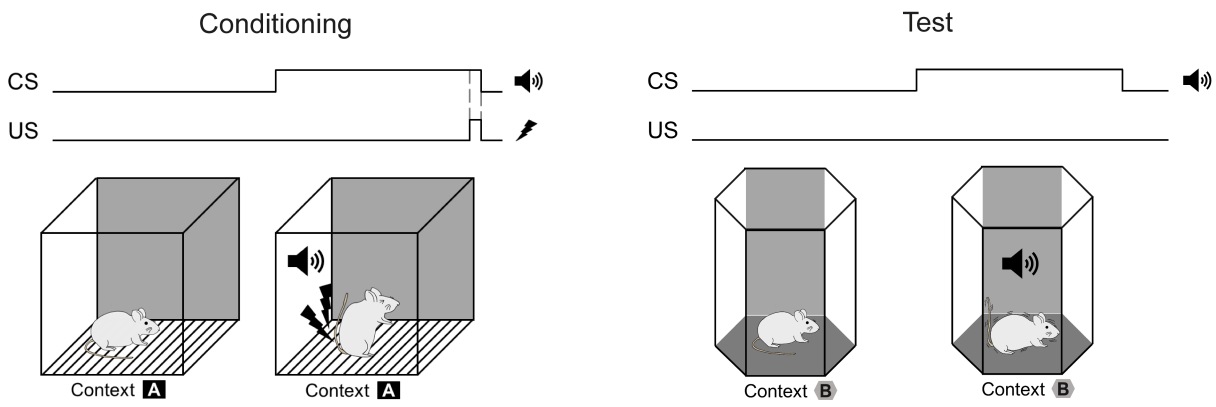

\section{B Contextual Fear Conditioning}

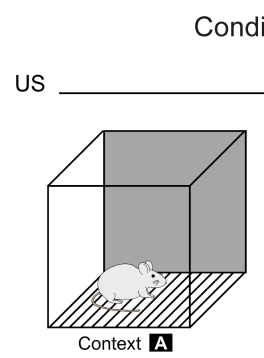

onditioning

Test

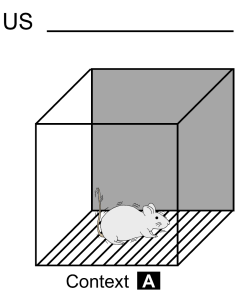

Context A

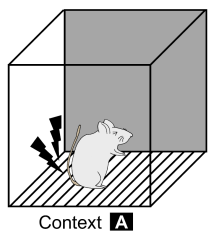

Fig. 3. Schematic diagram of delay (A), contextual (B), and trace $(\mathrm{C})$ fear conditioning. In delay conditioning (A), the conditioned stimulus (CS), e.g., a tone precedes and overlaps with the unconditioned stimulus (US), e.g., foot shock. In contextual conditioning (B), the US is administered in a conditioning context. In trace fear conditioning $(\mathrm{C})$, the CS and US are separated by a stimulus-free "trace interval" (dashed line).

used tasks for examining cognitive status in genetically modified mice, including AD mice $[45,46]$. The task was used for the first time to measure recognition memory in the rat, based on the rat's behavior to explore a novel object more than a familiar one [47]. Although there is considerable variation in novel object recognition task procedures, this task is typically conducted in a familiar square or rectangular high-walled arena lacking evident spatial cues (Fig. 4). After habituation to the arena, the rats are exposed to two identical objects. After a delay, rats are exposed to a familiar and a new object. Rats typically spend more time exploring the new object than the familiar one.

Rats with hippocampal lesions exhibited impairments in the novel object recognition task $[48,49]$. The status of recognition memory with different delays has been examined in several inbred mice. Inbred strain differences have been observed in some studies but not others $[27,50]$. It was reported that DBA/2 mice performed worse than C57BL/6 mice in this task [51]. However, it is difficult to compare between studies because there are numerous potential variations of this task, such as the delay interval, size of arena, and scoring methods used.

\section{Assessment of memory using retention of exposure to novel olfactory/gustatory information}

Rodents, including mice, tend to avoid the ingestion of novel foods. This initial neophobia is decreased with repeated exposure to the novel food. Our laboratory examined differences in reten- 
Novel Object Recognition
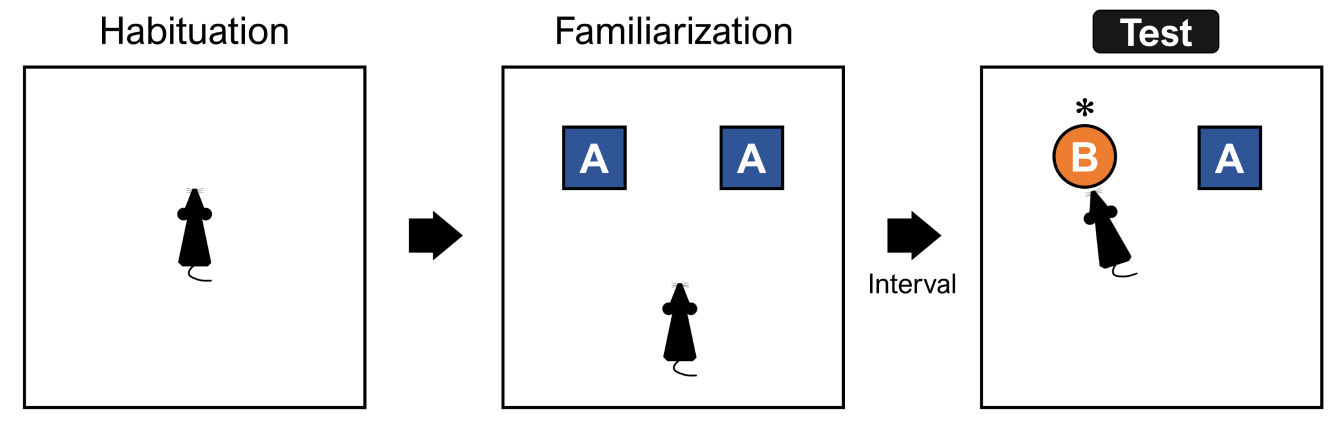

Fig. 4. Schematic diagram of the novel object recognition task. A mouse is habituated to the arena (left) and familiarized with two identical objects. After a specific interval, a novel object is presented to a mouse. tion of exposure to novel olfactory/gustatory information in two inbred mouse strains. Consumption levels of C57BL/6 mice were significantly increased compared to those of DBA/2 mice (Fig. 5). It could be interpreted that C57BL/6 mice remembered and recognized the novel food that they were previously exposed to better than DBA/2 mice.

\section{PAVLOVIAN APPETITIVE CONDITIONING IN GENETICALLY MODIFIED MICE}

Pavlovian conditioning is one of the most systematically studied subjects by psychologists [52]. In order to reveal the cognitive phenotype of genetically modified mice, Pavlovian aversive conditioning, an association of CS with aversive US, has been extensively used, while Pavlovian appetitive conditioning with an appetitive US, such as food or water, is not prevalent. The principle of associative learning and its neural mechanisms have been studied and revealed mostly by Pavlovian appetitive conditioning using rats as subjects. A number of studies that have identified a specific cognitive function with Pavlovian appetitive conditioning have been introduced.

The traditional view of conditioning is that it is a passive and automatic process, but it is now clear that conditioning is affected by predictive and informational relationships between CS and US [53]. The establishment of a predictive relationship between a CS and a motivationally significant US through Pavlovian conditioning can endow the CS with motivational and emotional power. For example, a neutral CS (e.g., light or tone) paired with food delivery acquires incentive motivation. Therefore, this CS reinforces later the Pavlovian conditioning or instrumental conditioning and modulates the performance of other learned or unlearned responses (e.g., lever pressing for food; eating food) [54, 55]. Although the neural mechanisms and circuitry for cognitive function, including attention and reward expectancy, have been studied in rats and monkeys, mouse models are valuable for understand-
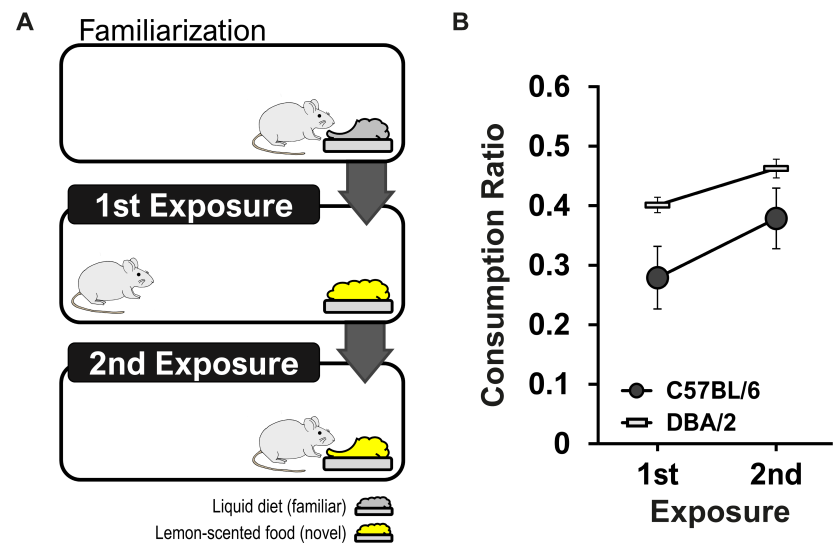

Fig. 5. (A) Behavioral procedure for neophobia. The initial lemonscented diet was given to mice after habituation to a plain liquid diet. The second lemon-scented diet was given 3 days later. (B) Suppression ratios of mice on exposure to the baseline liquid diet, when a non-nutritive flavor was added. Suppression ratio $=$ Lemon-scented diet $/$ (lemon-scented diet + baseline diet). Male C57BL/6 $(\mathrm{n}=10)$ and DBA/2 $(\mathrm{n}=10)$ mice exhibited suppressed consumption at the initial exposure and retained that experience later, as indicated by the absence of suppression relative to baseline. There was a significant difference in the consumption ratio between $\mathrm{C} 57 \mathrm{BL} / 6$ and DBA/2 mice $(\mathrm{F}[1,18]=4.40, \mathrm{p}<0.05)$. These data are from unpublished work in our laboratory.

ing the cellular and molecular mechanism of these cognitive functions. A mouse-based paradigm to examine Pavlovian influences on instrumental conditioning has been developed (Fig. 6) [56].

Genetically modified mice targeting molecular and cellular mechanisms underlying synaptic plasticity and learning and memory development have been used to reveal the involvement of genes in appetitive incentive learning. For example, mice with knock-in mutations in the phosphorylation sites of alpha-amino3-hydroxy-5-methylisoxazole-4-propionic acid (AMPA) receptor subunit GluR1 exhibited impairments of synaptic plasticity and memory retention [57]. These phosphomutants also exhibited impairment in appetitive incentive learning $[56,58]$. Deletion of pentraxin, which is regulated by neuronal activity and co-clustered 


\section{A Phase 1}

Pavlovian Conditioning

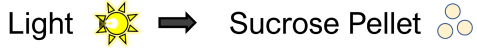
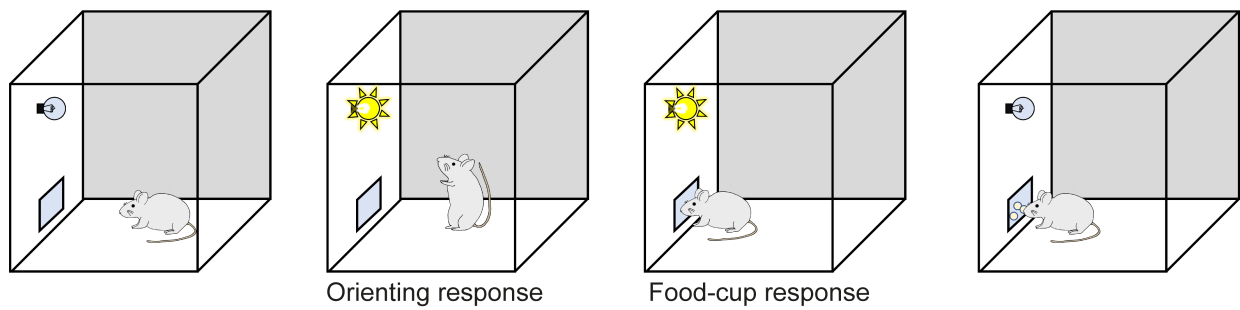

\section{B Phase 2}

Instrumental Conditioning

Lever pressing $\Rightarrow$ Sucrose Pellet $\circ$
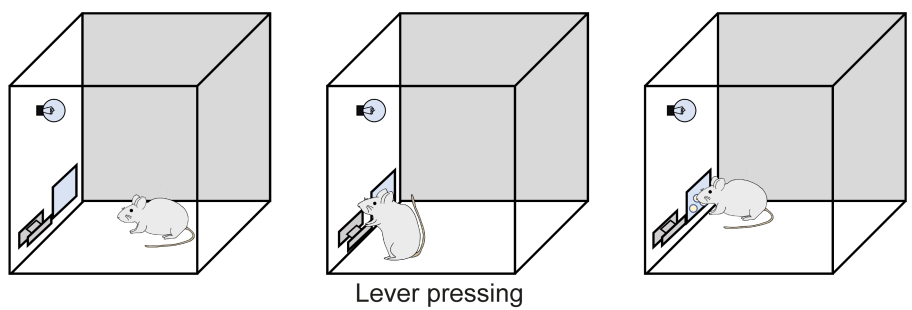

\section{Phase 3}

Pavlovian-Instrumental Transfer

Light $\Rightarrow$ Lever pressing
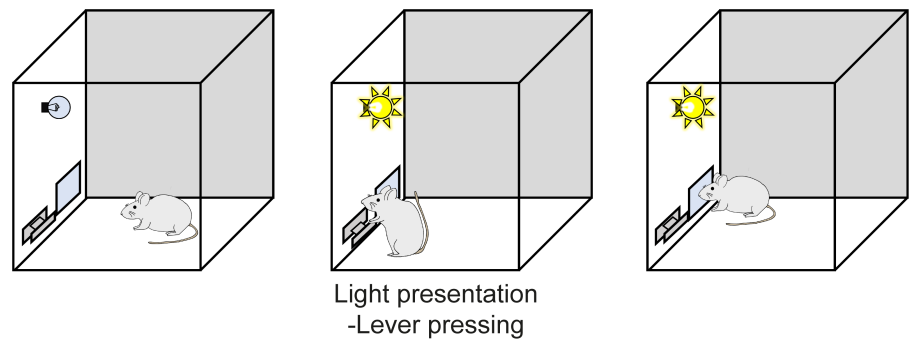

Fig. 6. Schematic diagram of a Pavlovian-instrumental transfer. A mouse receives Pavlovian pairings of a conditioned stimulus, such as a light with a reward (A), and then instrumental conditioning with sucrose pellets (B). The ability of the CS to serve as a conditioned reinforcer is assessed (C).

with AMPA receptors, affected the processing of sensory-specific incentive value [59]. It has been reported that the BDNF receptor, TrkB, known to play a key role in neural development and plasticity, is critical for the acquisition of appetitive incentive learning [60]. Motivational function, as measured using appetitive incentive learning, was impoverished in transgenic mice expressing a putative dominant-negative disrupted in schizophrenia 1 [61].

\section{COGNITIVE TESTS IN AD MICE}

$\mathrm{AD}$ is a neurodegenerative disorder characterized by progres- sive decline of cognitive function [62]. Mouse AD models are essential for understanding the basic underlying biology of AD and developing therapeutic drugs. Three mouse models of AD and three cognitive assays that are frequently used are summarized in Table 1 (also reviewed in $[63,64]$ ). Some AD studies using animals have used only female mice. This is due to reports showing that accumulated levels of amyloid beta and plaque in female mice were higher than those in male mice in some AD mouse models [65-68]. However, sex differences in $\mathrm{AD}$ pathology in $\mathrm{AD}$ mouse models is still controversial (reviewed in [69]). Furthermore, because the frequency and length of the estrous cycle changes with age [70], and 
Table 1. Transgenic mouse models of Alzheimer's diseases and typical cognitive assays

\begin{tabular}{|c|c|c|c|c|}
\hline $\begin{array}{l}\text { Behavioral } \\
\text { Task }\end{array}$ & Test & Age & Description & $\begin{array}{l}\text { Refer- } \\
\text { ences }\end{array}$ \\
\hline \multicolumn{5}{|l|}{$\operatorname{Tg} 2576$} \\
\hline \multirow[t]{4}{*}{$\begin{array}{l}\text { Morris water } \\
\text { maze }\end{array}$} & $\begin{array}{l}\text { Hidden platform and visible plat- } \\
\text { form test }\end{array}$ & $2 \sim 3,6,9 \sim 10$ months & $\begin{array}{l}\text { Tg2576 mice aged 9 10 months showed spatial } \\
\text { memory impairment }\end{array}$ & {$[76]$} \\
\hline & $\begin{array}{l}\text { Hidden platform and visible plat- } \\
\text { form test }\end{array}$ & $\begin{array}{l}4 \sim 5,6 \sim 11,12 \sim 18 \\
20 \sim 25 \text { months }\end{array}$ & $\begin{array}{l}\text { Tg2576 mice aged } 12 \sim 18 \text { and } 20 \sim 25 \text { months showed } \\
\text { spatial memory impairment }\end{array}$ & {$[77]$} \\
\hline & Hidden platform test & $\begin{array}{l}6 \text { and } 12 \text { months } \\
\text { (female) }\end{array}$ & $\begin{array}{l}\text { Tg } 2576 \text { mice aged } 6 \text { and } 12 \text { months showed spatial } \\
\text { memory impairment }\end{array}$ & {$[78]$} \\
\hline & Hidden platform test & $\begin{array}{l}16 \text { and } 17 \text { months } \\
\text { (female) }\end{array}$ & Tg2576 mice showed spatial memory impairment & {$[79,80]$} \\
\hline \multirow[t]{4}{*}{$\begin{array}{l}\text { Fear condi- } \\
\text { tioning }\end{array}$} & $\begin{array}{l}\text { Trace fear conditioning and delay } \\
\text { fear conditioning }\end{array}$ & $5 \sim 6$ months & $\begin{array}{l}\text { Tg2576 mice exhibited deficit in only trace fear condi- } \\
\text { tioning }\end{array}$ & {$[81]$} \\
\hline & $\begin{array}{l}\text { Contextual fear conditioning and } \\
\text { cued fear conditioning }\end{array}$ & 5 and 9 months & $\begin{array}{l}\text { Tg2 } 2576 \text { mice showed memory impairment in contextu- } \\
\text { al fear conditioning, but not in cued fear conditioning, } \\
\text { at both aged } 5 \text { and } 9 \text { months }\end{array}$ & {$[82]$} \\
\hline & Contextual fear conditioning & 8 months (female) & $\begin{array}{l}\text { Tg2576 mice showed memory impairment in contex- } \\
\text { tual fear conditioning }\end{array}$ & {$[83]$} \\
\hline & $\begin{array}{l}\text { Contextual fear conditioning and } \\
\text { cued fear conditioning }\end{array}$ & 17 months (female) & $\begin{array}{l}\text { Tg2576 mice (B6SJL background) showed memory } \\
\text { impairment in contextual fear conditioning, but not in } \\
\text { cued fear conditioning }\end{array}$ & {$[80]$} \\
\hline \multirow[t]{4}{*}{$\begin{array}{l}\text { Novel object } \\
\text { recognition }\end{array}$} & Delay 24 hrs & $\begin{array}{l}3,6,12 \text { months } \\
\text { (female) }\end{array}$ & $\begin{array}{l}\text { Tg } 2576 \text { mice aged } 6 \text { and } 12 \text { months showed deficit } \\
\text { recognition memory }\end{array}$ & {$[78]$} \\
\hline & Delay $2 \mathrm{~min}, 4 \mathrm{hrs}$ and $24 \mathrm{hrs}$ & 5 months & $\begin{array}{l}\text { Tg2576 mice exhibit a deficit in test with } 4 \text { hrs and } 24 \\
\text { hrs delay }\end{array}$ & [84] \\
\hline & Delay $1 \mathrm{hr}$ & 8 months (female) & Tg2576 mice showed recognition memory impairment & {$[83]$} \\
\hline & Delay $1 \mathrm{hr}$ and $24 \mathrm{hrs}$ & 16 months (female) & $\begin{array}{l}\text { Tg2 } 2576 \text { mice showed recognition memory impairment } \\
\text { in both } 1 \mathrm{hr} \text { and } 24 \text { hrs delay in test }\end{array}$ & [79] \\
\hline \multicolumn{5}{|l|}{$A P P / P S 1(\triangle E 9)$} \\
\hline \multirow{3}{*}{$\begin{array}{l}\text { Morris water } \\
\text { maze }\end{array}$} & Hidden platform test & 7 months & APP/PS1 mice showed a learning deficit & {$[85,86]$} \\
\hline & Hidden platform test & 9 months & $\begin{array}{l}\mathrm{APP} / \mathrm{PS} 1 \text { mice showed spatial memory impairment in } \\
\text { retention probe test }\end{array}$ & {$[87]$} \\
\hline & $\begin{array}{l}\text { Hidden platform and } \\
\text { Visible platform test }\end{array}$ & $10 \sim 12$ months & $\begin{array}{l}\text { APP/PS1 mice showed spatial memory impairment. No } \\
\text { differences during the visible platform test }\end{array}$ & {$[88-90]$} \\
\hline \multirow{3}{*}{$\begin{array}{l}\text { Fear condi- } \\
\text { tioning }\end{array}$} & Contextual fear conditioning & $6,9,11$ months & APP/PS1 mice showed cognitive impairment & {$[87]$} \\
\hline & $\begin{array}{l}\text { Contextual fear conditioning and } \\
\text { cued fear conditioning }\end{array}$ & 10 12 months & $\begin{array}{l}\text { APP/PS1 mice showed memory impairment in both } \\
\text { cued and contextual fear conditioning }\end{array}$ & {$[88]$} \\
\hline & Cued fear conditioning & 12 14 months & $\begin{array}{l}\text { APP/PS1 mice showed memory impairment in cued } \\
\text { fear conditioning }\end{array}$ & {$[91]$} \\
\hline \multirow[t]{3}{*}{$\begin{array}{l}\text { Novel object } \\
\text { recognition }\end{array}$} & Delay $1 \mathrm{hr}$ & 7 months & $\begin{array}{l}\text { APP/PS1 mice showed impairment of cognitive } \\
\text { function }\end{array}$ & {$[92]$} \\
\hline & Delay 4 hrs & 10 months (female) & $\begin{array}{l}\text { APP/PS1 mice showed impairment of cognitive } \\
\text { function }\end{array}$ & [93] \\
\hline & Delay 24 hrs & $\begin{array}{l}6 \text { and } 12 \text { months } \\
\text { (male) }\end{array}$ & $\begin{array}{l}\text { Behavioral deficit was only observed in APP/PS1 mice } \\
\text { at } 12 \text { months old }\end{array}$ & {$[94]$} \\
\hline \multicolumn{5}{|c|}{ 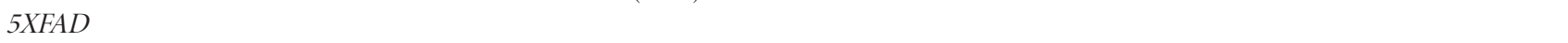 } \\
\hline \multirow[t]{3}{*}{$\begin{array}{l}\text { Morris water } \\
\text { maze }\end{array}$} & Hidden platform test & $\begin{array}{l}3,6,9 \text { months } \\
\text { (Male) }\end{array}$ & $\begin{array}{l}\text { 5XFAD mice aged } 9 \text { months showed spatial reference } \\
\text { memory impairment }\end{array}$ & {$[95]$} \\
\hline & Hidden platform test & $5 \sim 6$ months & $\begin{array}{l}\text { 5XFAD mice showed spatial reference memory impair- } \\
\text { ment }\end{array}$ & {$[81]$} \\
\hline & Hidden platform test & $7 \sim 9$ months & $\begin{array}{l}\text { 5XFAD mice showed spatial reference memory impair- } \\
\text { ment }\end{array}$ & {$[96]$} \\
\hline
\end{tabular}


Table 1. Continued

\begin{tabular}{|c|c|c|c|c|}
\hline $\begin{array}{l}\text { Behavioral } \\
\text { Task }\end{array}$ & Test & Age & Description & $\begin{array}{l}\text { Refer- } \\
\text { ences }\end{array}$ \\
\hline \multirow[t]{3}{*}{$\begin{array}{l}\text { Fear condi- } \\
\text { tioning }\end{array}$} & Contextual fear conditioning & $\begin{array}{l}3 \sim 4,6 \sim 7,12 \sim 13 \\
\text { months }\end{array}$ & $\begin{array}{l}\text { 5XFAD mice aged 6-7 and 12-13 months showed } \\
\text { context-associated fear memory impairment }\end{array}$ & {$[97]$} \\
\hline & Contextual fear conditioning & 6 months & $\begin{array}{l}\text { 5XFAD mice showed context-associated fear memory } \\
\text { impairment }\end{array}$ & {$[98]$} \\
\hline & $\begin{array}{l}\text { Trace fear conditioning and delay } \\
\text { fear conditioning }\end{array}$ & $5 \sim 6$ months & $\begin{array}{l}\text { 5XFAD mice showed significantly lower freezing } \\
\text { response than respective wild-type littermate mice in } \\
\text { trace but not delay fear conditioning }\end{array}$ & {$[81]$} \\
\hline \multirow[t]{3}{*}{$\begin{array}{l}\text { Novel object } \\
\text { recognition }\end{array}$} & Delay $1 \mathrm{hr}$ & 4 months (Female) & $\begin{array}{l}\text { 5XFAD mice showed cognitive impairment in novel } \\
\text { object recognition test }\end{array}$ & [99] \\
\hline & Delay 24 hrs & $\begin{array}{l}6 \sim 8 \text { months }(\mathrm{Fe}- \\
\text { male) }\end{array}$ & $\begin{array}{l}\text { 5XFAD mice showed cognitive impairment in novel } \\
\text { object recognition test }\end{array}$ & {$[100]$} \\
\hline & Delay 24 hrs & 6 and 12 months & $\begin{array}{l}\text { 5XFAD mice aged } 6 \text { and } 12 \text { months showed cognitive } \\
\text { impairment }\end{array}$ & {$[101]$} \\
\hline
\end{tabular}

In studies where the sex has not been specified under Age, both male and female mice were used or no information on sex was provided.

neuroplasticity is affected by levels of estrogen [71], a measurement of cognitive status of AD mice should be carefully conducted $[72,73]$.

The present review introduces interesting findings regarding the decline of cognitive flexibility in aged mice or AD mice using a behavioral task based on the modified behavioral protocol of a redundant place/cue version of the water maze task described earlier (Fig. 1). Twenty-three-month-old aged mice and 12-monthold adult mice were serially trained in cued and place versions of the water maze task and then underwent a strategy preference test (Fig. 2). Aged and adult mice showed no differences in cued and place training, but, on the preference test, the aged mice chose a cued strategy more frequently than the adult mice [74]. We also examined the learning strategy preferences of 5XFAD mice using this same training protocol. No differences between 5XFAD and non-transgenic control mice were observed in cued and place training. However, in the strategy preference test, the 5XFAD mice preferred more often a cued strategy than control mice [75].

\section{CONCLUSIONS}

Numerous researchers have raised the question of how many behavioral tests are necessary and what tests are key in revealing the phenotype of their genetically modified mice. There is no single answer to this question. When using an experimental design with appropriate control groups and comparison conditions, the choice of a cognitive test should be optimized to address the investigator's hypotheses based on anatomical and neurophysiological results.

Behavioral and neurobiological findings regarding cognitive function have largely come from studies of mice, rats, and primates. However, researchers have tried to apply parameters and behavioral protocols used in studies with rats to mouse studies, without considering behavioral and physiological differences between rats and mice. As a result, although it takes a lot of time and effort, a study is sometimes not successful. Therefore, parameters and behavioral protocols appropriate for a mouse study might be useful for studying cognitive functions in AD transgenic mice, or in mice with conditional gene targeting using Cre-LoxP recombination.

\section{ACKNOWLEDGEMENTS}

This work was funded by the R \& D Convergence Program of the Republic of Korea National Research Council of Science \& Technology (grant numbers CRC-15-04-KIST, G15120, G16230, K16850, and K17850) and by the Korea Research Foundation Grant funded by the Korean Government (NRF2017R1A2B4011540 and NRF-2014R1A1A2058480).

\section{REFERENCES}

1. Crawley JN (2008) Behavioral phenotyping strategies for mutant mice. Neuron 57:809-818.

2. Crawley JN, Belknap JK, Collins A, Crabbe JC, Frankel W, Henderson N, Hitzemann RJ, Maxson SC, Miner LL, Silva AJ, Wehner JM, Wynshaw-Boris A, Paylor R (1997) Behavioral phenotypes of inbred mouse strains: implications and recommendations for molecular studies. Psychopharmacology (Berl) 132:107-124.

3. Crawley JN, Paylor R (1997) A proposed test battery and constellations of specific behavioral paradigms to investigate the behavioral phenotypes of transgenic and knockout mice. 
Horm Behav 31:197-211.

4. Ruys T (1991) Handbook of facilities planning. Volume 2. Laboratory animal facilities. Van Nostrand Reinhold, New York, NY.

5. Crabbe JC, Wahlsten D, Dudek BC (1999) Genetics of mouse behavior: interactions with laboratory environment. Science 284:1670-1672.

6. Cho WH, Han JS (2016) Differences in the flexibility of switching learning strategies and CREB phosphorylation levels in prefrontal cortex, dorsal striatum and hippocampus in two inbred strains of mice. Front Behav Neurosci 10:176.

7. Paylor R, Spencer CM, Yuva-Paylor LA, Pieke-Dahl S (2006) The use of behavioral test batteries, II: effect of test interval. Physiol Behav 87:95-102.

8. Sung JY, Goo JS, Lee DE, Jin DQ, Bizon JL, Gallagher M, Han JS (2008) Learning strategy selection in the water maze and hippocampal CREB phosphorylation differ in two inbred strains of mice. Learn Mem 15:183-188.

9. Bothe GW, Bolivar VJ, Vedder MJ, Geistfeld JG (2004) Genetic and behavioral differences among five inbred mouse strains commonly used in the production of transgenic and knockout mice. Genes Brain Behav 3:149-157.

10. Brooks SP, Pask T, Jones L, Dunnett SB (2004) Behavioural profiles of inbred mouse strains used as transgenic backgrounds. I: motor tests. Genes Brain Behav 3:206-215.

11. Upchurch M, Wehner JM (1989) Inheritance of spatial learning ability in inbred mice: a classical genetic analysis. Behav Neurosci 103:1251-1258.

12. Wahlsten D, Cooper SF, Crabbe JC (2005) Different rankings of inbred mouse strains on the Morris maze and a refined 4-arm water escape task. Behav Brain Res 165:36-51.

13. Wehner JM, Radcliffe RA, Bowers BJ (2001) Quantitative genetics and mouse behavior. Annu Rev Neurosci 24:845-867.

14. Ammassari-Teule M, Passino E, Restivo L, de Marsanich B (2000) Fear conditioning in C57/BL/6 and DBA/2 mice: variability in nucleus accumbens function according to the strain predisposition to show contextual- or cue-based responding. Eur J Neurosci 12:4467-4474.

15. Balogh SA, Radcliffe RA, Logue SF, Wehner JM (2002) Contextual and cued fear conditioning in C57BL/6J and DBA/2J mice: context discrimination and the effects of retention interval. Behav Neurosci 116:947-957.

16. Bampton ET, Gray RA, Large CH (1999) Electrophysiological characterisation of the dentate gyrus in five inbred strains of mouse. Brain Res 841:123-134.

17. Hwang YK, Song JC, Han SH, Cho J, Smith DR, Gallagher M, Han JS (2010) Differences in hippocampal CREB phosphory- lation in trace fear conditioning of two inbred mouse strains. Brain Res 1345:156-163.

18. Matsuyama S, Namgung U, Routtenberg A (1997) Long-term potentiation persistence greater in $\mathrm{C} 57 \mathrm{BL} / 6$ than $\mathrm{DBA} / 2$ mice: predicted on basis of protein kinase $\mathrm{C}$ levels and learning performance. Brain Res 763:127-130.

19. Paylor R, Tracy R, Wehner J, Rudy JW (1994) DBA/2 and C57BL/ 6 mice differ in contextual fear but not auditory fear conditioning. Behav Neurosci 108:810-817.

20. Wehner JM, Sleight S, Upchurch M (1990) Hippocampal protein kinase $\mathrm{C}$ activity is reduced in poor spatial learners. Brain Res 523:181-187.

21. Nguyen PV (2006) Comparative plasticity of brain synapses in inbred mouse strains. J Exp Biol 209:2293-2303.

22. Lee YS (2014) Genes and signaling pathways involved in memory enhancement in mutant mice. Mol Brain 7:43.

23. Lee YS, Silva AJ (2009) The molecular and cellular biology of enhanced cognition. Nat Rev Neurosci 10:126-140.

24. Passino E, Middei S, Restivo L, Bertaina-Anglade V, Ammassari-Teule M (2002) Genetic approach to variability of memory systems: analysis of place vs. response learning and fos-related expression in hippocampal and striatal areas of C57BL/6 and DBA/2 mice. Hippocampus 12:63-75.

25. Paylor R, Baskall L, Wehner JM (1993) Behavioral dissociations between C57BL/6 and DBA/2 mice on learning and memory tasks: a hippocampal-dysfunction hypothesis. Psychobiology (Austin Tex) 21:11-26.

26. Ammassari-Teule M, Caprioli A (1985) Spatial learning and memory, maze running strategies and cholinergic mechanisms in two inbred strains of mice. Behav Brain Res 17:9-16.

27. Brooks SP, Pask T, Jones L, Dunnett SB (2005) Behavioural profiles of inbred mouse strains used as transgenic backgrounds. II: cognitive tests. Genes Brain Behav 4:307-317.

28. Middei S, Vetere G, Sgobio C, Ammassari-Teule M (2007) Landmark-based but not vestibular-based orientation elicits mossy fiber synaptogenesis in the mouse hippocampus. Neurobiol Learn Mem 87:174-180.

29. Owen EH, Logue SF, Rasmussen DL, Wehner JM (1997) Assessment of learning by the Morris water task and fear conditioning in inbred mouse strains and F1 hybrids: implications of genetic background for single gene mutations and quantitative trait loci analyses. Neuroscience 80:1087-1099.

30. Nguyen PV, Abel T, Kandel ER, Bourtchouladze R (2000) Strain-dependent differences in LTP and hippocampusdependent memory in inbred mice. Learn Mem 7:170-179.

31. Hwang YK, Han JS (2008) Striatal CREB phosphorylation following cued/response learning in the water maze differ in 
two inbred strains of mice. Exp Neurobiol 17:41-46.

32. McDonald RJ, White NM (1994) Parallel information processing in the water maze: evidence for independent memory systems involving dorsal striatum and hippocampus. Behav Neural Biol 61:260-270.

33. Cho WH, Park JC, Jeon WK, Cho J, Han JS (2019) Superior place learning of $\mathrm{C} 57 \mathrm{BL} / 6$ vs. DBA/2 mice following prior cued learning in the water maze depends on prefrontal cortical subregions. Front Behav Neurosci 13:11.

34. Fanselow MS, Poulos AM (2005) The neuroscience of mammalian associative learning. Annu Rev Psychol 56:207-234.

35. Maren S, Quirk GJ (2004) Neuronal signalling of fear memory. Nat Rev Neurosci 5:844-852.

36. Anagnostaras SG, Gale GD, Fanselow MS (2001) Hippocampus and contextual fear conditioning: recent controversies and advances. Hippocampus 11:8-17.

37. Maren S, Holt W (2000) The hippocampus and contextual memory retrieval in Pavlovian conditioning. Behav Brain Res 110:97-108.

38. McEchron MD, Disterhoft JF (1999) Hippocampal encoding of non-spatial trace conditioning. Hippocampus 9:385-396.

39. Crestani F, Keist R, Fritschy JM, Benke D, Vogt K, Prut L, Blüthmann H, Möhler H, Rudolph U (2002) Trace fear conditioning involves hippocampal $\alpha_{5} G_{A B A}$ receptors. Proc Natl Acad Sci U S A 99:8980-8985.

40. Huerta PT, Sun LD, Wilson MA, Tonegawa S (2000) Formation of temporal memory requires NMDA receptors within CA1 pyramidal neurons. Neuron 25:473-480.

41. Nie T, Abel T (2001) Fear conditioning in inbred mouse strains: an analysis of the time course of memory. Behav Neurosci 115:951-956.

42. Stanciu M, Radulovic J, Spiess J (2001) Phosphorylated cAMP response element binding protein in the mouse brain after fear conditioning: relationship to Fos production. Brain Res Mol Brain Res 94:15-24.

43. Võikar V, Kõks S, Vasar E, Rauvala H (2001) Strain and gender differences in the behavior of mouse lines commonly used in transgenic studies. Physiol Behav 72:271-281.

44. Smith DR, Gallagher M, Stanton ME (2007) Genetic background differences and nonassociative effects in mouse trace fear conditioning. Learn Mem 14:597-605.

45. Bang E, Lee B, Park JO, Jang Y, Kim A, Kim S, Shin HS (2018) The improving effect of HL271, a chemical derivative of metformin, a popular drug for type II diabetes mellitus, on aginginduced cognitive decline. Exp Neurobiol 27:45-56.

46. Cohen SJ, Stackman RW Jr (2015) Assessing rodent hippocampal involvement in the novel object recognition task. A review. Behav Brain Res 285:105-117.

47. Ennaceur A, Delacour J (1988) A new one-trial test for neurobiological studies of memory in rats. 1: behavioral data. Behav Brain Res 31:47-59.

48. Broadbent NJ, Gaskin S, Squire LR, Clark RE (2009) Object recognition memory and the rodent hippocampus. Learn Mem 17:5-11.

49. Clark RE, Zola SM, Squire LR (2000) Impaired recognition memory in rats after damage to the hippocampus. J Neurosci 20:8853-8860.

50. Sik A, van Nieuwehuyzen P, Prickaerts J, Blokland A (2003) Performance of different mouse strains in an object recognition task. Behav Brain Res 147:49-54.

51. Podhorna J, Brown RE (2002) Strain differences in activity and emotionality do not account for differences in learning and memory performance between C57BL/6 and DBA/2 mice. Genes Brain Behav 1:96-110.

52. Rescorla RA (1988) Pavlovian conditioning. It's not what you think it is. Am Psychol 43:151-160.

53. Holland PC (1993) Cognitive aspects of classical conditioning. Curr Opin Neurobiol 3:230-236.

54. Holland PC, Gallagher M (2003) Double dissociation of the effects of lesions of basolateral and central amygdala on conditioned stimulus-potentiated feeding and Pavlovianinstrumental transfer. Eur J Neurosci 17:1680-1694.

55. Holland PC, Petrovich GD, Gallagher M (2002) The effects of amygdala lesions on conditioned stimulus-potentiated eating in rats. Physiol Behav 76:117-129.

56. Crombag HS, Galarce EM, Holland PC (2008) Pavlovian influences on goal-directed behavior in mice: the role of cuereinforcer relations. Learn Mem 15:299-303.

57. Lee HK, Takamiya K, Han JS, Man H, Kim CH, Rumbaugh G, Yu S, Ding L, He C, Petralia RS, Wenthold RJ, Gallagher M, Huganir RL (2003) Phosphorylation of the AMPA receptor GluR1 subunit is required for synaptic plasticity and retention of spatial memory. Cell 112:631-643.

58. Crombag HS, Sutton JM, Takamiya K, Lee HK, Holland PC, Gallagher M, Huganir RL (2008) A necessary role for GluR1 serine 831 phosphorylation in appetitive incentive learning. Behav Brain Res 191:178-183.

59. Johnson AW, Crombag HS, Takamiya K, Baraban JM, Holland PC, Huganir RL, Reti IM (2007) A selective role for neuronal activity regulated pentraxin in the processing of sensory-specific incentive value. J Neurosci 27:13430-13435.

60. Johnson AW, Chen X, Crombag HS, Zhang C, Smith DR, Shokat KM, Gallagher M, Holland PC, Ginty DD (2008) The brain-derived neurotrophic factor receptor TrkB is critical for 
the acquisition but not expression of conditioned incentive value. Eur J Neurosci 28:997-1002.

61. Johnson AW, Jaaro-Peled H, Shahani N, Sedlak TW, Zoubovsky S, Burruss D, Emiliani F, Sawa A, Gallagher M (2013) Cognitive and motivational deficits together with prefrontal oxidative stress in a mouse model for neuropsychiatric illness. Proc Natl Acad Sci U S A 110:12462-12467.

62. Ballard C, Gauthier S, Corbett A, Brayne C, Aarsland D, Jones E (2011) Alzheimer's disease. Lancet 377:1019-1031.

63. Puzzo D, Lee L, Palmeri A, Calabrese G, Arancio O (2014) Behavioral assays with mouse models of Alzheimer's disease: practical considerations and guidelines. Biochem Pharmacol 88:450-467.

64. Lee JE, Han PL (2013) An update of animal models of Alzheimer disease with a reevaluation of plaque depositions. Exp Neurobiol 22:84-95.

65. Callahan MJ, Lipinski WJ, Bian F, Durham RA, Pack A, Walker LC (2001) Augmented senile plaque load in aged female $\beta$-amyloid precursor protein-transgenic mice. Am J Pathol 158:1173-1177.

66. Gallagher JJ, Minogue AM, Lynch MA (2013) Impaired performance of female APP/PS1 mice in the Morris water maze is coupled with increased $A \beta$ accumulation and microglial activation. Neurodegener Dis 11:33-41.

67. Jiao SS, Bu XL, Liu YH, Zhu C, Wang QH, Shen LL, Liu CH, Wang YR, Yao XQ, Wang YJ (2016) Sex dimorphism profile of Alzheimer's disease-type pathologies in an APP/PS1 mouse model. Neurotox Res 29:256-266.

68. Bundy JL, Vied C, Badger C, Nowakowski RS (2018) Sexbiased hippocampal pathology in the 5XFAD mouse model of Alzheimer's disease: a multi-omic analysis. J Comp Neurol.

69. Dubal DB, Broestl L, Worden K (2012) Sex and gonadal hormones in mouse models of Alzheimer's disease: what is relevant to the human condition? Biol Sex Differ 3:24.

70. Nelson JF, Felicio LS, Randall PK, Sims C, Finch CE (1982) A longitudinal study of estrous cyclicity in aging C57BL/6J mice: I. Cycle frequency, length and vaginal cytology. Biol Reprod 27:327-339.

71. Woolley CS, Gould E, Frankfurt M, McEwen BS (1990) Naturally occurring fluctuation in dendritic spine density on adult hippocampal pyramidal neurons. J Neurosci 10:4035-4039.

72. Farr SA, Flood JF, Scherrer JF, Kaiser FE, Taylor GT, Morley JE (1995) Effect of ovarian steroids on footshock avoidance learning and retention in female mice. Physiol Behav 58:715723.

73. Frick KM, Berger-Sweeney J (2001) Spatial reference memory and neocortical neurochemistry vary with the estrous cycle in C57BL/6 mice. Behav Neurosci 115:229-237.

74. Nicolle MM, Prescott S, Bizon JL (2003) Emergence of a cue strategy preference on the water maze task in aged C57B6 $\mathrm{x}$ SJL F1 hybrid mice. Learn Mem 10:520-524.

75. Cho WH, Park JC, Chung C, Jeon WK, Han JS (2014) Learning strategy preference of 5XFAD transgenic mice depends on the sequence of place/spatial and cued training in the water maze task. Behav Brain Res 273:116-122.

76. Hsiao K, Chapman P, Nilsen S, Eckman C, Harigaya Y, Younkin S, Yang F, Cole G (1996) Correlative memory deficits, $A \beta$ elevation, and amyloid plaques in transgenic mice. Science 274:99-102.

77. Westerman MA, Cooper-Blacketer D, Mariash A, Kotilinek L, Kawarabayashi T, Younkin LH, Carlson GA, Younkin SG, Ashe KH (2002) The relationship between A $\beta$ and memory in the Tg2576 mouse model of Alzheimer's disease. J Neurosci 22:1858-1867.

78. Ohta H, Arai S, Akita K, Ohta T, Fukuda S (2012) Effects of NK-4 in a transgenic mouse model of Alzheimer's disease. PLoS One 7:e30007.

79. Gerenu G, Dobarro M, Ramirez MJ, Gil-Bea FJ (2013) Early cognitive stimulation compensates for memory and pathological changes in Tg2576 mice. Biochim Biophys Acta 1832:837-847.

80. Lassalle JM, Halley H, Daumas S, Verret L, Francés B (2008) Effects of the genetic background on cognitive performances of TG2576 mice. Behav Brain Res 191:104-110.

81. Ohno M, Chang L, Tseng W, Oakley H, Citron M, Klein WL, Vassar R, Disterhoft JF (2006) Temporal memory deficits in Alzheimer's mouse models: rescue by genetic deletion of BACE1. Eur J Neurosci 23:251-260.

82. Dineley KT, Xia X, Bui D, Sweatt JD, Zheng H (2002) Accelerated plaque accumulation, associative learning deficits, and up-regulation of a7 nicotinic receptor protein in transgenic mice co-expressing mutant human presenilin 1 and amyloid precursor proteins. J Biol Chem 277:22768-22780.

83. Dobarro M, Gerenu G, Ramírez MJ (2013) Propranolol reduces cognitive deficits, amyloid and tau pathology in Alzheimer's transgenic mice. Int J Neuropsychopharmacol 16:2245-2257.

84. Taglialatela G, Hogan D, Zhang WR, Dineley KT (2009) Intermediate- and long-term recognition memory deficits in Tg2576 mice are reversed with acute calcineurin inhibition. Behav Brain Res 200:95-99.

85. Bernardo A, Harrison FE, McCord M, Zhao J, Bruchey A, Davies SS, Jackson Roberts L 2nd, Mathews PM, Matsuoka Y, Ariga T, Yu RK, Thompson R, McDonald MP (2009) Elimi- 
nation of GD3 synthase improves memory and reduces amyloid- $\beta$ plaque load in transgenic mice. Neurobiol Aging 30:1777-1791.

86. Ding Y, Qiao A, Wang Z, Goodwin JS, Lee ES, Block ML, Allsbrook M, McDonald MP, Fan GH (2008) Retinoic acid attenuates $\beta$-amyloid deposition and rescues memory deficits in an Alzheimer's disease transgenic mouse model. J Neurosci 28:11622-11634.

87. Cramer PE, Cirrito JR, Wesson DW, Lee CY, Karlo JC, Zinn AE, Casali BT, Restivo JL, Goebel WD, James MJ, Brunden KR, Wilson DA, Landreth GE (2012) ApoE-directed therapeutics rapidly clear $\beta$-amyloid and reverse deficits in $A D$ mouse models. Science 335:1503-1506.

88. Ma T, Du X, Pick JE, Sui G, Brownlee M, Klann E (2012) Glucagon-like peptide- 1 cleavage product GLP-1(9-36) amide rescues synaptic plasticity and memory deficits in Alzheimer's disease model mice. J Neurosci 32:13701-13708.

89. Lalonde R, Kim HD, Maxwell JA, Fukuchi K (2005) Exploratory activity and spatial learning in 12-month-old APP(695) SWE/co+PS1/DeltaE9 mice with amyloid plaques. Neurosci Lett 390:87-92.

90. Zhang W, Hao J, Liu R, Zhang Z, Lei G, Su C, Miao J, Li Z (2011) Soluble A $\beta$ levels correlate with cognitive deficits in the 12-month-old APPswe/PS1dE9 mouse model of Alzheimer's disease. Behav Brain Res 222:342-350.

91. Knafo S, Venero C, Merino-Serrais P, Fernaud-Espinosa I, Gonzalez-Soriano J, Ferrer I, Santpere G, DeFelipe J (2009) Morphological alterations to neurons of the amygdala and impaired fear conditioning in a transgenic mouse model of Alzheimer's disease. J Pathol 219:41-51.

92. Zhang R, Xue G, Wang S, Zhang L, Shi C, Xie X (2012) Novel object recognition as a facile behavior test for evaluating drug effects in A $\beta$ PP/PS1 Alzheimer's disease mouse model. J Alzheimers Dis 31:801-812.

93. Donkin JJ, Stukas S, Hirsch-Reinshagen V, Namjoshi D, Wilkinson A, May S, Chan J, Fan J, Collins J, Wellington CL (2010) ATP-binding cassette transporter A1 mediates the beneficial effects of the liver X receptor agonist GW3965 on object recognition memory and amyloid burden in amyloid precursor protein/presenilin 1 mice. J Biol Chem 285:3414434154.

94. Mori T, Rezai-Zadeh K, Koyama N, Arendash GW, Yamaguchi H, Kakuda N, Horikoshi-Sakuraba Y, Tan J, Town T (2012) Tannic acid is a natural $\beta$-secretase inhibitor that prevents cognitive impairment and mitigates Alzheimer-like pathology in transgenic mice. J Biol Chem 287:6912-6927.

95. Schneider F, Baldauf K, Wetzel W, Reymann KG (2014) Behavioral and EEG changes in male 5xFAD mice. Physiol Behav 135:25-33.

96. Urano T, Tohda C (2010) Icariin improves memory impairment in Alzheimer's disease model mice (5xFAD) and attenuates amyloid $\beta$-induced neurite atrophy. Phytother Res 24:1658-1663.

97. Devi L, Ohno M (2010) Genetic reductions of beta-site amyloid precursor protein-cleaving enzyme 1 and amyloid- $\beta$ ameliorate impairment of conditioned taste aversion memory in 5XFAD Alzheimer's disease model mice. Eur J Neurosci 31:110-118.

98. Park JC, Ma J, Jeon WK, Han JS (2016) Fructus mume extracts alleviate cognitive impairments in 5XFAD transgenic mice. BMC Complement Altern Med 16:54.

99. Giannoni P, Gaven F, de Bundel D, Baranger K, MarchettiGauthier E, Roman FS, Valjent E, Marin P, Bockaert J, Rivera S, Claeysen S (2013) Early administration of RS 67333, a specific 5-HT4 receptor agonist, prevents amyloidogenesis and behavioral deficits in the 5XFAD mouse model of Alzheimer's disease. Front Aging Neurosci 5:96.

100. Tohda C, Urano T, Umezaki M, Nemere I, Kuboyama T (2012) Diosgenin is an exogenous activator of 1,25D3-MARRS/ Pdia3/ERp57 and improves Alzheimer's disease pathologies in 5XFAD mice. Sci Rep 2:535.

101. Wang D, Fu Q, Zhou Y, Xu B, Shi Q, Igwe B, Matt L, Hell JW, Wisely EV, Oddo S, Xiang YK (2013) $\beta 2$ adrenergic receptor, protein kinase A (PKA) and c-Jun N-terminal kinase (JNK) signaling pathways mediate tau pathology in Alzheimer disease models. J Biol Chem 288:10298-10307. 